\title{
The Implementation of Good Corporate Governance: Required Quality of Management Accounting Information System? (Empirical Evidence on Sharia Banking Institutions in Bandung City, Indonesia)
}

\section{Rini Lestari, Diamonalisa Sofianty, Edi Sukarmanto, and Nurleli}

Faculty of Economics and Business, Universitas Islam Bandung

\section{Abstract}

The aim of this study is to explain that the quality of management accounting information systems is able to influence the implementation of good corporate governance on sharia banking institutions in Bandung city, Indonesia. A contribution of thought to the Financial Services Authority (OJK) in enforcing regulations on the implementation of good governance on sharia banking institutions is the result from this study. The research method used was a data collection survey through questionnaires as the instrument of research to the respondents who are managers in sharia banking institutions. The population was 42 sharia banking institutions in Bandung city, Indonesia. The target of population was all 12 institutions of sharia commercial banks in Bandung city in 2017 period. All targets of population are taken as samples by using nonprobability sampling technique with convenience sampling method. And analysis of simple linear regression method is as the hypothesis testing. The quality of management accounting information system positively and significantly influences to the implementation of good corporate governance on sharia banking institutions in Bandung city, Indonesia, as it is shown by the results. In other words, it can be said that the better quality of management accounting information system is needed as it will make the better implementation of good corporate governance on sharia banking institutions in Bandung city, Indonesia as well.

Keywords: quality of management accounting information system, good corporate governance, sharia banking institution

\section{Introduction}

The monetary crisis has now developed into a multi-dimensional crisis including the S OPEN ACCESS 
and big companies become bankrupt due to the weak implementation of good corporate governance (GCG). It appears in the lack of corporate transparency, especially for the companies that have not been go public; the lack of commissioner empowerment as an organ of supervision on management activities; and, the inability of accountants and auditors to contribute to the company financial oversight system (Fauzi, 2016). The problems of governance in sharia banking institutions are very different from conventional banks. First, sharia banks are obliged to adhere to the sharia principles in carrying out its business activities. Second, the potential for information asymmetry is very high for sharia banking. This is related to the issue of accountability and transparency on the fund use of customers and shareholders (Algaoud \& Lewis, 2001). The weak or the poor implementation of GCG in both banking and non-banking institutions causes they could not achieve one of the goals of maximum profit (Suhartono, 2012). This can be evidenced from the annual report of a sharia banking institution. It is known as a Sharia Public Bank and it becomes the first pioneer on the birth of banking institutions. It runssyariat/Islamic rules in its operations namely Bank Muamalat Indonesia (BMI). We can see the data on the achievement of net profit per share at BMI from 2012 to 2017 in Table 1 as follow:

TABlE 1: Achievement on per share of Net Profit at Bank Muamalat Indonesia (in billions of rupiah).

\begin{tabular}{|l|c|c|c|c|c|c|}
\hline Information & 2017 & 2016 & 2015 & 2014 & 2013 & 2012 \\
\hline Per share of Net Profit & 5.90 & 7.89 & 7.30 & 5.77 & 21.73 & 30.88 \\
\hline Source: Bank Muamalat Indonesia, 2018. & & & & \\
\hline
\end{tabular}

From the aforementioned table, we can see that the financial performance of BMI, one of the largest sharia banking institutions in Indonesia is not in a good condition. It has been explained earlier that the low of financial performance, occurring in several years, can be caused by the low implementation of good corporate governance on BMI. The implementation of good corporate governance in sharia banking institutions has already been regulated in Bank Indonesia Regulation Number 11/33/Pbi/2009 concerning Implementation of Good Corporate Governance, for Sharia Commercial Banks, and Article 2 paragraph (1),for Sharia Business Units. Now, in 2015, Financial Services Authority (OJK) sets new rules about GCG Implementation in sharia banking institutions. It is done in every activity of banks to improve the performance of sharia banking institutions both in terms of receipt and distribution of funds from the community. However, the implementation of good corporate governance (GCG) in sharia banking institutions is experiencing various obstacles over the years and through the development of information technology. One of the obstacles, especially Sharia Commercial Bank, is the low quality of management accounting information system in several 
sharia commercial banks. In some sharia banks, software as part of the components in management accounting information systems is still not fully integrated as it makes it still less effective. The customer service information systems also causes problem. It often leads to various complaints from customers (Winarsih, 2005).

Based on the aforementioned description, this article will discuss the issue: how the influence of the quality of management accounting information system to the implementation of good corporate governance on sharia banking institutions in Bandung city, Indonesia.

\section{Literature Review}

The quality of management accounting information system (MAIS) can be interpreted as a form of statement about the conditions which it can generate useful information for managers in running the management process (Hoque, 2003: 4). Furthermore, it can be shown from the user satisfaction of the information system in relation to the fulfillment of their needs in decision making (Susanto, 2017).

Good Corporate Governance (GCG) can be defined as corporate organ activity in conducting corporate activities as a legal entity, either internally or in relation to outside of corporate stakeholders (KNKG, 2006). The implementation of GCG in sharia banking institutions becomes an undeniable necessity. Even they must emerge as the foremost pioneers in implementing the GCG because they bring religious names into business institutions. Based on Bank Indonesia Regulation Number 11/33/Pbi/2009 concerning Implementation of Good Corporate Governance, for Sharia Commercial Bank; Unit Article 2 paragraph (1), for Sharia Business; and also the Decree/ Suratkeputusan from OJK (2015); explains that Bank is obliged to implement GCG in every business activity at all levels of the organization.

\section{Research Framework}

The issues of governance in sharia banking are very different from conventional banks so that it is the imperative of sharia banking institutions as pioneers of GCG enforcement as it is compared to conventional banks, according to Algaoud and Lewis (2001), because, first, sharia banks have an obligation to comply with sharia principles (sharia compliance) in running their business. As a result, Sharia Supervisory Board (DPS) plays an important role in the governance structure of sharia banking. Second, the agency theory problem becomes very relevant because the potential for asymmetry 
information is very high for sharia banking. The quality of management accounting information system is necessary in every activity of sharia banking institutions to minimize the risk of asymmetry information. It will influence the implementation of good corporate governance (GCG). This is evidenced by the research results of Kaplan \& Nagel (2004); Watters, et al. (2008); Williams \& Seaman (2010); MK \& HM (2011); HanMing Wang \& Huyuh (2014); Rahnama \& Jalili (2015); Susanto (2015); Uyar, Gungormus \& Kuzey (2017).

Based on the aforementioned framework, the research hypothesis of this study is: the quality of MAIS influences on the implementation of good corporate governance.

\section{Methods}

The method which is used by the researcher during the investigation to solve the problem is research method (Kothari, 2004: 08). This study uses survey research as the research method. Fink (2003) in Sekaran \& Bougie (2013: 102) states that 'a survey is a system for collecting information from or about people to describe, to compare, or to explain their knowledge, attitudes, and behavior'. In survey method, researchers do not only provide an overview of the phenomena, but also explain the relation, test the hypotheses, make predictions and get the meaning and implications of a problem to be solved(Nazir, 2011: 56).

In this study, the population is all of 42 sharia banking institutions in Bandung city (OJK, 2017) with the target of all 12 institutions of Sharia Commercial Banks in Bandung city in 2017period. It will be sampled using nonprobability sampling technique with convenience sampling method which is determined by collecting how many companies (sharia commercial bank) are willing to be sampled (Ulum and Juanda, 2016: 84). Questionnaires were distributed in over two to three months. As the result, there are only 9 from 12 sharia banks in Bandung city that filled in and returned the questionnaire, so the number of samples is 9 companies (sharia commercial banks). The collecting technique is to spread the questionnaire. The questionnaire is given directly to 34 operational managers in sharia banks in Bandung city. It contains questions to obtain information about the quality of management accounting information systems and the implementation of good corporate governance.

Operational definition of each variable can be stated as follow: first variable, The quality of management accounting information system (MAIS), can be interpreted as a form of statement about 'the conditions under which MAIS can generate useful information for managers in running the management process and for fulfilling user 
satisfaction' (Hoque, 2003: 4; Susanto, 2017). And it can be measured from several dimensions, namely: '(1) integration, (2) accessibility, (3) flexibility, (4) formalization and (5) media richness' (Heidmann, 2008: 45). Second variable, Implementation of Good Corporate Governance (GCG) can be defined as 'corporate organ activity in conducting corporate activities as a legal entity, either internally or in relation to outside of corporate stakeholders' (KNKG, 2006). Implementation of GCG on syariah banking institutions will be measured from the application of GCG principles consisting of: '(1) transparency, accountability, responsibility, independency and fairness' (OECD, 2004; KNKG, 2006).

Further, hypothesis testing research is conducted using simple linear regression analysis. It is used to find out how the influence of the quality of management accounting information system to the implementation of good corporate governance. In addition, to predict how far the changes in the value of the dependent variable when it is fluctuated or up and down used this method of analysis.

\section{Results and Discussion}

In the previous chapter, it has been formulated the research hypothesis. The quality of Management Accounting Information System (MAIS) influences on the Implementation of Good Corporate Governance (GCG). It is done by using analysis of simple linear regression. Before hypothesis testing and significance test are done, firstly, the research instrument is tested for its validity and its reliability. Then it is followed by the data normality test. Based on the validity test, each item of questions in the questionnaire with 34 respondents, r table value can be obtained through r table of product moment Pearson with $\mathrm{df}$ (degree of freedom) $=n-2$, so $\mathrm{df}=34-2=32$, then $r$ table $=0.291$. It is shown that all items are valid because it has $r$ count value $>$ 0.291. Further, the result of reliability testing can be seen at Cronbach's Alpha value, if Alpha value $>0.7$ the statements construct as dimension variable is reliable. Cronbach's Alpha value is 0.857 . It is above 0.70 so that it is reliable, which means the items on each dimension variable are reliable to measure each variable. They can be used for hypothesis testing. And all data in the study is stated in normal distribution. We can be seen the results of hypothesis testing by using analysis of simple linear regression and significance testing in the following table.

Based on Table 2, it can be obtained the regression equation as follows: $Y=1.119$ $+0.572 X$.It can be interpreted that if the quality of MAIS variable improves by one point, the implementation of GCG variable will also increase by 0.572 . In other words, 
TABle 2: Analysis of Simple Linear Regression Coefficients ${ }^{a}$.

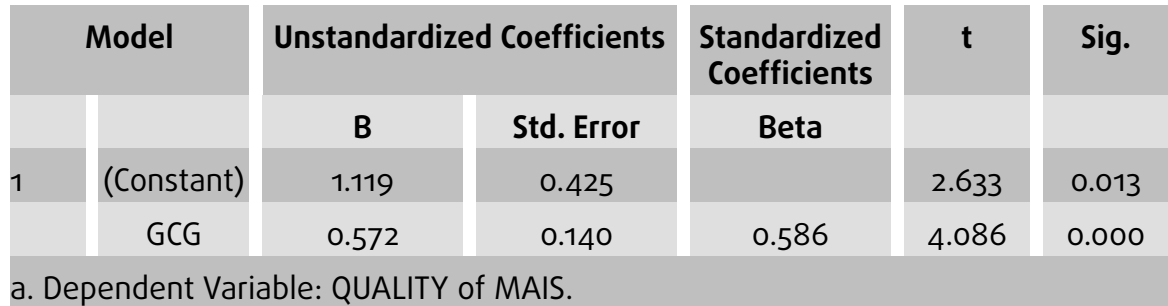

the better the quality of MAIS, it can improve the better implementation of GCG. Furthermore, from Table 2, it can be said there is a significant influence because the sig is 0.000 which means $<0.005$. Then $\mathrm{Ho}$ is rejected and $\mathrm{Ha}$ is accepted, which means the quality of MAIS significantly influences on the implementation of GCG. It can be seen from the following table of determination coefficient test to know how the influence of the quality of MAIS on implementation of GCG:

TABle 3: Determination Coefficient Test Model Summary.

\begin{tabular}{|c|c|c|c|c|}
\hline Model & $\mathbf{R}$ & R Square & $\begin{array}{l}\text { Adjusted R } \\
\text { Square }\end{array}$ & $\begin{array}{l}\text { Std. Error of the } \\
\text { Estimate }\end{array}$ \\
\hline 1 & $0.586^{a}$ & 0.343 & 0.322 & 0.50387 \\
\hline
\end{tabular}

The aforementioned table shows that the influence of quality of MAIS on implementation of GCG is 0.343 or $34.3 \%$. In other words, quality of MAIS variable by $34.3 \%$ (enough category) can explain or influence implementation of GCG variables while other variables explain or influence the rest of $65.7 \%$. They are not examined in this study, such as organizational culture (Jonathan, 2001), enforcement (Claessens, 2006), new regulation (Ghazali, 2010), and the wider environmental (Christopher, 2010).The previous research result from Kaplan \& Nagel (2004); Watters, et al. (2008); Williams \&Seaman (2010); MK \& HM (2011); Han-Ming Wang \& Huyuh (2014); Rahnama \& Jalili (2015); Susanto (2015); Uyar, Gungormus \& Kuzey (2017) support the result of hypothesis testing in this study.

The study result indicates the quality of MAIS positively and significantly influences to implementation of GCG. It can be explained that if the quality of a good management accounting information system is owned by a company, it will have integrated and comprehensive system. The system can generate and disseminate information to help managers perform their functions ranging from planning, controlling and remaking decision. In other words, if a company has a good quality of management accounting information system it will support the implementation of good corporate governance. Furthermore, the company (sharia commercial bank) can reduce the occurrence of 
asymmetry information with the quality of management accounting information system so that the principle of transparency, accountability, responsibility, independency and equality and fairness in the implementation of good corporate governance can be done properly. Therefore the implementation of GCG in sharia banking institutions requires quality of management accounting information system.

The implications may contribute as a recommendation for sharia commercial banks to improve the quality of management accounting information systems so it can produce useful information for decision makers to implement Good Corporate Governance. This study has limitations that the results could not be generalized widely because it only applies to sharia banking institutions in Bandung city, so it is recommended for researchers to further expand the generalization area by expanding the target population.

\section{Conclusion}

The study results prove that the quality of management accounting information system positively and significantly influences on the implementation of Good Corporate Governance based on validity and reliability test and hypothesis testing. It shows that the quality of management accounting information system is needed in the implementation of good corporate governance in sharia banking institutions in Bandung city, Indonesia, because the better quality of management accounting information system will result in the better implementation of good corporate governance.

\section{Acknowledgement}

The authors would like to thank the Faculty of Economics and Business, University of Islam Bandung, for supporting this study. They are also grateful to the Dean of the Faculty of Economics and Business and the Chairman of Accounting Program in University of Islam Bandung.

\section{Funding}

The study has been entirely funded by the Accounting Study Program and Faculty of Economics and Business, University of Islam Bandung. 


\section{References}

[1] Algaoud, L. M. and Lewis, M. K. (2001). Islamic Banking. Massachusetts: Islamic Edward Elgar.

[2] Bank Muamalat Indonesia. (2018). Retrieved from www.bankmuamalat.co.id. laporan (accessed 1 April 2018).

[3] Fauzi, A. (2016). Analisis Penerapan Good Corporate Governance terhadap Kualitas Laba. Retrieved from digilib.unila.ac.id

[4] Christopher, J. (2010). Corporate Governance-A multi-theoretical approach to recognizing the wider influencing force impacting on organizations. Critical Perspectives on Accounting, vol. 21, no. 8, pp. 683-695.

[5] Stijn, C. and Berglof, E. Enforcement and good corporate governance in developing countries and transition economies. The World Bank Research Observer, vol. 21, no. 1, pp. 123-150.

[6] Ghazali, M. and Nazli, A. (2010). Ownership structure, corporate governance and corporate performance in Malaysia. International Journal of Commerce and Management, vol. 20, no. 2, pp. 109-119.

[7] Wang, H.-M., David, and Huyuh, Q. L. (2014). The role of corporate governance in the link between management accounting system and firm performance. Asian Journal of Finance \& Accounting, vol. 6, no. 1.

[8] Heidmann, M. (2008). The Role of Management Accounting Systems in Strategic Sensemaking (first edition). Germany: Deutscher Universitats.

[9] Hoque, Z. (2003). Strategic Management Accounting: Concepts, Process and Issues (second edition). Great Britain: Biddless.

[10] Batten, J. and lu, J. (2001). The implementation of OECD corporate governance principles in post-crisis Asia. Journal of Corporate Citizenship, vol. 4, no. December, pp. 47-62.

[11] Kaplan, R. S. and Nagel, M. E. (2004). Improving Corporate Governance with the Balanced Scorecard. Division of Research: Harvard Business School.

[12] Komite Nasional Kebijakan Governance. (2006). Pedoman Umum Good Corporate Governance Indonesia.

[13] Kothari, C. R. (2004). Research Methodology (Methods and Techniques), (second revised edition). New Age International Publisher.

[14] Mayanja, M. K. and Van der Poll, H. M. (November 2011). Management accounting: An instrument for implementing effective corporate governance. African Journal of Business Management, vol. 5, no. 30. 
[15] Nazir, M. (2011). Metode Penelitian. Bogor: Ghalia Indonesia.

[16] Otoritas Jasa Keuangan. (2018). Buku Statistik Bank Syariah 2017.

[17] OECD. (2004). Principle of Corporate Governance.

[18] Rahnama, A. \& Jalili, A. (2015). Examining the impact of corporate governance on relation of management accounting system and performance of listed companies in Tehran Stock Exchange. Journal of Scientific Research and Development, vol. 2, no. 4, pp. 6-10.

[19] Sekaran, U. and Bougie, R. (2013). Research Methods for Business. A Skill Building Approach (sixth edition). United Kingdom. John Wiley \& Sons Ltd.

[20] Susanto, A. (December 2015). Influence the quality of accounting information on the implementation good study program governance. International Journal of Scientific \& Technology Research, vol. 4, no. 12.

[21] _ (2017). How the quality of accounting information system impact on accounting information quality (Research on Higher Education in Bandung). Journal of Engineering and Applied Science, vol. 12, no. 14, pp. 3672-3677.

[22] Ulum, I. and Juanda, A. (2016). Metodologi Penelition Akuntonsi: Klinik Skripsi (Edisi 2). Malang: Aditya Media Publisher.

[23] Uyar, A., Gungormus, H. A., and Kuzey, C. (2017). Impact of the accounting information system on corporate governance: Evidence from Turkish non-listed companies. Australasian Accounting, Business and Finance Journal, vol. 11, no. 1.

[24] Watters, C. S., Zimmerman, J. L., and Morse, D. (2008). Management Accounting Analysis and

[25] Interpretation. New York, NY: Mc Graw-Hill Irwin.

[26] Williams, J. J. and Seaman, A. E. (2010). Corporate governance \& mindfulness: The impact of management accounting system change. The Journal of Applied Business Research, vol. 26, no. 5 .

[27] Winarsih, A. S. (2005). Penerapan Citizen's Character dan Standar Pelayanan Minimal. Yogyakarta: Pustaka Pengajar. 